\title{
Development of student's work sheet based on contextual approach of the sequence and series material
}

\author{
Ita Desnatalia ${ }^{1}$, I Made Arnawa ${ }^{2}$, Irwan Irwan ${ }^{3}$ \\ ${ }^{123}$ Universitas Negeri Padang, Padang - Indonesia, (itadesnatalia@yahoo.com)
}

\begin{abstract}
Using Mathematics Student Worksheet (LKS) which is made by teachers before hasn't been effective to help students in learning process. Therefore, the mathematics LKS needs to be developed to help students to find the concept themselves. Sequence and series material is important in mathematics at Vocational High School (SMK), and yet students still find difficulty to understand it. The aim of this development is to produce mathematics LKS based on contextual approach which is valid, practical and effective. This development research uses a formative evaluation model by Tjeerd Plomp. The subject of the research is the second year students of SMKN 6 Padang. Validation is done by experts / lecturers. The practicality of LKS is seen from the observation of the implementation of learning, practicality questionnaires, and interviews conducted with students and teachers. Effectiveness is seen from the results of activities and student learning outcomes.
\end{abstract}

Keywords: contextual, activity of study, plomp.

\section{Introduction}

One of the subsystems in National Education is the implementation of vocational education at secondary education level called Vocational High School or Sekolah Menengah Kejuruan (SMK). SMK is an education program that prepares students to have particular skills and to be ready to face the challenges of the industrial world in the current era of globalization. SMK is a kind of education that equips its graduates with certain competencies in order to be ready to use in a field of work after completing education. The success of education in vocational school is determined by the quality of the graduates, which describes individuals who have noble character, healthy, knowledgeable, capable, creative, independent and responsible (Depdiknas, 2006).

SMKN 6 Padang, where the author teaches, uses KTSP as curriculum reference learning in the academic year 2015-2016. Mathematics belongs to a group of adaptive subjects. Mathematics is also a compulsory subject for the student as one of the subjects tested in the national exam. Based on the preliminary observation that the writer did to the learning instrument, it was seen that the present teaching materials depends on the government's textbooks, teaching materials and student worksheets or Lembar Kerja siswa (LKS) made by team mathematics teachers at the school. The LKS certainly does not have a standard of validity, practicality and effectiveness because the LKS has not been revised by the experts who are competent in its field but was only revised by the team teachers in the school. 
Based on the result of interview with mathematic teachers, the teaching materials and the LKS that are being used are already a good sources for students. However, if the teaching materials are developed well with a learning approach it will certainly produce more meaningful learning for students. The presentation of teaching materials, sample of problems, and exercices in LKS surely can be more developed in order to facilitate students to understand it. The presentation of materials on the LKS is seen unrelated to the problems that are encountered by the students in their daily life. The concept of direct learning is presented in the form of the definition and the use of mathematical symbols. This is certainly less interesting and not motivates students to learn math more. The learning which is presented to them certainly cannot give meaning to the students because it is less associated with daily life. Therefore, students do not see the benefits of the material being studied. Presentation of teaching materials in the worksheet looks less interesting for students to learn because it is directly presented in the form of symbols and mathematics language that is difficult to understand for them.

Characteristics of a vocational student who actively moves during practice in his field of expertise is less visible in the process of learning mathematics. Based on the writer's experience in teaching and observation that the writer did in SMKN 6 Padang, it is seen that student activities in the learning process is still not optimal. The similar topic also frequently becomes the topic discussions of fellow math teachers at the vocational teachers organisation in Padang. Teachers often discuss about the problems that occur in the learning process in the class. Students are less able to demonstrate positive activity in mathematics class. Community or good learning communities between students in the learning process have been seen not optimal. High-ability students are less eager to share knowledge with low-ability students, and vice versa. They work individualy based on their mathematical abilities. Students asking questions, giving opinions in the discussion can be improved.

The results of writer's interview with 10 students informs that there are students who are less interested in studying mathematics because it is considered difficult and the materials given are less applicable in everyday life. Most students have not been able to connect what they learn to how that knowledge can be applied in their lives. Students tend to memorize the formula rather than understand the mathematical concepts given so that students are less able to determine and apply the mathematical concepts needed when given the exercise. Many students are confused to determine which concept is needed on a problem. Students tend to give up easily and are less motivated to solve math problems so they do the exercise less seriously.

Activities and learning outcomes to be achieved by the students on the learning process can be enhanced by the learning activities conducted in the classroom. Student activities and in the classroom can be improved by providing LKS. LKS will provide real guidance for the learning process. LKS is a guide that contains a set of basic activities that must be done by students to maximize understanding in order to establish the basic ability that match the indicators of learning achievements (Trianto, 2009). This is what encourages the writer to conduct a research development on teaching instrument that can guide students in understanding the concept of mathematics provided in the classroom by maximizing their understanding in order to form basic skills that match the indicators of learning achievement. The writer plans to design LKS which is organized systematically using a contextual approach that match the competencies which must be mastered by students.

By using the contextual based LKS, students actively practice constructing their own knowledge. Students not merely accept the concept presented by the teacher but the students themselves will build a concept of what has been seen, experienced, and known by them. Learning will be more meaningful if one experiences alone what is learned, not merely knowing. Contextual learning is based on the results of a study that reveals students will learn well if what is learned is related to what is already known and to the activities or events that occur around it (Hosnan, 2006). Contextual Teaching and Learning (CTL) is one of the learning approaches that fulfill that expectation. CTL has 
seven principles that form the philosophical foundation that is also called the CTL components of constructivism, inquiry, questioning, modeling, reflection, and real judgment (Suyadi, 2014). Contextual approaches have the concept that teachers present real-world situations into the classroom and encourage students to make connections between their knowledge and application in their lives. CTL is a learning that is used to understand the meaning of the subject matter by linking the material in the context of the student's daily life (Zainal, 2014). Contextual learning is based on the four pillars of education proclaimed by UNESCO namely 1) learning to do, 2) learning to know, 3) learning to be, and 4) learning to live together. Each kind of learning is expected to empower students to be willing/ready and able to enrich the learning experience. With contextual learning, it is expected that students can build understanding and knowledge of the surrounding world that will foster selfconfidence so as to generate positive attitudes and behaviors in students.

Effective teaching is teaching that provides opportunities for self-study or self-activity. Learning activities are diverse such as visual activity activities; reading, viewing pictures, observing, experimenting, demonstration and more; oral activities that include the activities of presenting facts or principles, linking an event, asking questions, giving suggestions, expressing opinions, interviews, discussions and interruptions, listening activities such as listening to material presentations, listening to conversations, radio and others, writing activities in the form of writing reports, summarize, do the exercises, test and fill in the questionnaire; drawing activities such as painting and graphs, charts, maps, patterns and so on; metrics such as experimenting, selecting tools, conducting exhibitions, modeling, etc. and other mental activities such as thinking, remembering, problem solving, analyzing, decision making activities. there are Emotional activities such as interest, courage, calm and so on (Hamalik, 2008).

The writer is focusing on the development of LKS on the Sequence and series material. The material is often found in the test of academic potential that is very necessary in supporting the formation of student intelligence. After completing education, Students of SMK will plunge into the world of work that demands creativity, high work and discipline. The results of field observations on teachers who have taught material sequence and series, in general, the ability of students in solving problems using the concept of sequence and series has not been satisfactory. Students' ability to link issues given to the context of their daily lives is still lacking. This of course affects the learning outcomes in the sequence and the sequence material. Many students get low grades for the sequence and series.

The unsatisfied result in classroom learning will affect the result of the national exam. The percentage of questions for the sequence and series material in the national exam is quite high (about $15-20 \%)$. There are 6-8 questions related sequence and series of 40 questions on national exam for mathematics for SMK.

Based on the above circumstances, the writer plans to develope contextual approached based LKS for sequence and series material in the hope improving the students learning outcomes. By using a contextual approached LKS as a learning supporter, it is hoped that students can build or construct their own knowledge to solve the given math problem using the concept of sequence and series. Besides, the learning process is expected to form a good learning community so that student learning activities increase.

The formulation of the problem in this research is "How is the process and result of LKS development based on a valid, practical, and effective contextual approach for sequence and series material in class XI SMK to improve student's learning activity and result?" And the purpose of the research is to know the processss and the result of a valid, practical, and effective contextual approached based LKS in the sequence and series materials in Grade XI SMK to improve student activities and learning outcomes. 


\section{Method}

This research is a development study using the Plomp model, which consists of three phases, namely preliminary research phase, prototyping stage, and assessment stage (Plomp, 2010). The preliminary research phase consists of needs analysis, curriculum analysis, concept analysis and student analysis. In the prototyping stage, the prototype is formative evaluation. Phase of development or prototype (prototyping stage) consists of prototype 1, that is self-evaluation (selfevaluation) and expert review; prototype 2 is one to one; prototype 3 is small group; prototype 4 , is field test. In the assessment stage, field test is conducted in class XI PH2 SMKN 6 Padang to see the practicality and effectiveness. Research data was collected through self-evaluation sheet, validation sheet, observation sheet and interview guide, teacher and student response questionnaire, student activaties observation sheet and final test of learning result. Two Mathematics lecturers, one Bahasa Indonesia lecturer, one lecturer of Educational Technology, and one Math teacher conduct the device validation.

\section{Results and Discussion}

The results of the research are preliminary analysis, results of development and assessment stage.

\section{Initial Investigation Results (Preliminary Analysis)}

The purpose of this stage is to state and define the requirements required in the development of mathematical worksheets. This stage is done by analyzing the objectives within the boundaries of the developed subject matter that is:

1. Needs Analysis; the information is collected by interviewing and observing the implementation of mathematics learning in the classroom. Interviews with teachers were conducted informally. This interview is related to several issues such as obstacles encountered by students in learning and topics that are considered difficult for students. The result obtained from the analysis of these needs is the currently used Mathematic LKS still have possibilities to be optimized. From the results of interviews with teachers, teachers explained that this is due to the teachers' limited ability in designing learning. The LKS used has not optimally assisted the students' ability to construct their own knowledge. The need of a valid, effective and effective mathematics LKS for teacher is needed.

2. Curriculum aims to analyze the standards competency and basic competencies of mathematics subjects on the curriculum KTSP 2006 for SMK. Without a good and proper curriculum, it will be difficult to reach the aspired goals and objectives of education. In this case, a review of the Education Unit Level Curriculum (KTSP) is used in SMKN 6 Padang for the Arts, Tourism and Home Technology Expertise Program. This analysis is conducted to study the material coverage, learning objectives, and strategies chosen as the foundation to develop LKS. This analysis is the selection of the indicator of the sequence and series material that will it LKS will be developed. This curriculum analysis aims to organize the material and determine the learning objectives to be achieved at each meeting.

3. Student Analysis was conducted by giving questionnaire to 10 students and four mathematics teacher of SMKN 6 Padang. This analysis aims to determine the characteristics of students that includes: students' academic abilities, learning styles, the level of thinking skills development and students' learning activities in mathematics. These interviews serve as the background of LKS design that will be developed to fit the characteristics of the students. The subject of this research are students of class XI SMKN 6 Padang.

4. Concept Analysis; at this stage it is conducted the activities of identifying, detailing, and systematically arranging the main materials that will be studied by students. Furthermore, the material is arranged in a hierarchical manner. Based on the material that will be developed, then 
sequence and series is arranged in outline, then it is specified, starting from the understanding of the sequence of numbers and series of numbers, how to find the pattern of number sequence, and its implementation in everyday life, how to find the concept of sequence and arithmetic series, how to find the concept of sequence and geometry series and uses the concept of sequence and series in solving everyday problem. Material sequence and series is used as optional material for the developed LKS because of the low student learning outcomes in this material yet urgent material in the national examination.

\section{Results of Development (Designing Prototype)}

1. Designing Learning Instrument; the result of Preliminary Research serves as the basis for the development or the manufacture of prototypes. Once the indicators are formulated as well as concept maps are established then the next step is to design learning instrument in the form of LKS. In the LKS which is developedd based on the standard of competence standards, basic competencies, indicators and learning objectives, the presentation of the material begins with a preliminary activity on short and interesting stories related to the daily life of the students to make learning is more meaningful. LKS contains contextual issues that students must solve completed with questions that can guide their thinking process to find out the concept of the material. It is named "Illustration". LKS provides a place for students to carry out inquiry activities on sequence and series materials. LKS contains examples to provide a place for students to make a lesson summary as a reflection stage. To see students' level of understanding, LKS has exercise questions as an assessment called "Student Activity". The questions presented encourage students to make connections between their knowledge and application in students' life. LKS uses a standard language that is communicative and unambiguous so that it is easily comprehended by the students. The use of new symbols and terms is explained in detail at the end of the subject (if any) so that students will not misunderstand the use of symbols and terms.

2. Prototype 1 is the initial stage of the LKS design result to obtain a valid device; 1) Self Evaluation Results is an activity of correcting small mistakes against yourself before consulting and discussing with experts. Aspects seen in the LKS are typing errors, punctuation accuracy, text size accuracy, precision of image placement and availability of empty spaces to solve problems. Frequent mistakes occur are; typo, punctuation is not spaced 1 spaces, the use of commas and exclamation marks or question marks. In addition, errors are also visible on the precise size of the image placement and the limited blank space to solve the problem; 2) Validation Results, the designed LKS were first discussed with the supervisor, then is validated to experts which consisted of 5: 2 Mathematics lecturers, 1 Math Teacher, 1 Language lecturer and 1 Eeducational Technology lecturer. The result of LKS validation reveals that for the didactic and material aspects the average validity is 3.37 , the category is very valid, the aspect of language is 3.50 , the category is very valid, and the aspect grafic is 3,70 with the category is very valid. The overall validity of LKS is 3.52 with very valid category.

3. Prototype 2, the individual evaluation is conducted by asking the students to comment on the designed LKS. LKS was given to 3 classes of XI grade students of Hair Beauty and XI Culinary 5 with heterogeneous ability within 4 times meeting. The undertaken activities are observing, recording responses, suggestions, and student questions about LKS. In addition, students filled in an observation sheet containing such things as the elusive part of the clues, the elusive sentences in problems, and the questions that students do not understand in the LKS. Overall, students are interested in the presentation of material on the LKS. The material is presented clearly and understood easily through the various activities contained in the LKS. Therefore, students are motivated to perform activities and answer the questions on the LKS. Revisions were made based on interviews and observations.

4. Prototype 3, after individual evaluation, small group evaluation was conducted by apllied LKS which had been designed to a group of students consisting of 6 people which are divided into 2 
groups with heterogeneous ability. Small group evaluation was conducted in class XI PH2 SMKN 6 Padang for 7 meetings. This activity is conducted to test the practicality of the developed LKS. At this stage, the observation is conducteed when the implementation of small group takes place. There are several revisions of LKS such as improving the presentation of LKS both in terms of color and the composition of the presentation. In the LKS also added symbols and additional information on student activities.

5. Field Test Results (prototype 4), the assessment stage (assessment stage) is prototype stage 4, where field test is conducted in class XI PH 2 SMKN 6 Padang to see the practicality and effectiveness of contextual approach based LKS. The try out of the test is conducted 6 times. The test field trials are Teacher and Learners Response Questionnaire. The result of practicality test and questionnaire of teacher response gives practical value of $86,7 \%$ with criteria very practical. The questionnaires reveals that teachers believe that the contextual approach based LKS, is easy to use, interesting, well understood, motivates students to learn math more actively. The result of questionnaire of student response shows that the level of LKS practicality from the aspect of ease of using, time efficiency, attractiveness, ease /comprehension, and advantage of LKS equal to $83,875 \%$ which belongs to very practical category.

\section{Assessment Stage}

1. Results of Student Activity Analysis, the types of activities observed were oral activities, writing activities, mental activities and emotional activities. In the observation of students activities, student activity in answering questions from teachers and expressing opinions are belong to low categories. Likewise, the activity of students in reporting group discussion is low. However, such activity tends to increase at each meeting. The same thing is seen in part of critical thinking that impacts on students' activities in making conclusions using their own words. The ability of students to think creatively and critically is low and it causes students to hesitate in summing up their learning.Learning using contextual approach based LKS makes students eager to read and do the problems in given exercises. The number of students who do not practice solving the math problem are less visible though there are a number of students who cheat with a group of friends. The activity of the students in working on the activities in the LKS has a positive impact on class atmospher. Students do not do other things that are not related to the learning process. From the observation, it is concluded that contextual approach based LKS has been effectively increases student-learning activity.

2. Test of Learning Achievement, the final test result is performed to see the effectiveness of LKS in terms of student learning evaluation during study. The learning achievement is obtained by test of learning achievement in the form of description test as much as 5 item. The test, which was held on January 16, 2016, was conducted to assess students' cognitive abilities after studying with contextual approach based LKS. The students who attended the daily test were 25 people. The final test results showed that students who scored above the KKM as many as 20 students from 25 students with an average of 76. There are students who still have not managed to achieve KKM, possibly cause of it is when the learning process takes place those students do not focus on the discussion and not seriously dothe exercises, thus causing students not able to answer the test questions well. From the results of this final test, $80 \%$ of students are above the KKM. This suggests that contextual approaches based LKS have been effectively improving student learning outcomes.

\section{Conclusions}

This research is a development research that produces contextual approach LKS which is valid, practical and efficient to increase students' activity and result of student learning in grade XI SMK. Based on this conclusion, the researcher suggested to develop LKS based on contextual approach on 
other materials. This research are also can be used as a guidance for the teacher in conducting the learning.

\section{Acknowledgments}

This research successfully conducted because of the help and contribution of various parties. The writer would like to thank Prof. Dr. I Made Arnawa, M.Si and Dr.H. Irwan, M.Si as lecturers who have provided guidance in the completion of this article., the team of validation, the Headmaster of SMKN 6 Padang, all the respondents, and all those who have helped the writer. The writer hopes that LKS that she has developed can be applied in school. This article is based on a thesis written by Ita Desnatalia entitled "Development of Learning-Based on Contextual Approach of the Sequence and Series Material for Vocational High School Students Of Secondary Grade ".

\section{References}

Depdiknas. (2006). Kurikulum Tingkat Satuan Pendidikan (KTSP). Jakarta: Depdiknas.

Trianto. (2009). Mendesain Model Pembelajaran Inovatif-Progesif. Jakarta: Kencana Prenada Media Kelompok.

Hosnan. (2014). Pendekatan Saintifik dan Kontekstual dalam Pembelajaran Abad 21. Jakarta : Ghalia Indonesia.

Suyadi, Didi. (2014). Pemecahan Masalah Matematika. (staf upi.edu/files/2011/06.Bab 4.Pdf, on june 6, 2015).

Zainal, (2014). Model-model, Media dan Strategi Pembelajaran Kontekstual (Inovatif). Bandung :Yrama Widya.

Hamalik, Oemar. (2008). Proses Belajar Mengajar. Jakarta: Bumi Aksara.

Plomp, T dan N. Nieveen. (2010). Educational Design Research. Enshede: Netherlands Institute for Curriculum Development (SLO). 